\begin{tabular}{|l|l|l|}
\hline \multicolumn{2}{|c|}{ PublisherInfo } \\
\hline \hline PublisherName & $:$ & BioMed Central \\
\hline \hline PublisherLocation & $:$ & London \\
\hline \hline PublisherImprintName & $:$ & BioMed Central \\
\hline \hline
\end{tabular}

\title{
Race relations gone cuckoo
}

\begin{tabular}{|l|l|l||}
\hline \multicolumn{2}{|c|}{ ArticleInfo } \\
\hline \hline ArticleID & $:$ & 3769 \\
\hline \hline ArticleDOI & $:$ & $10.1186 /$ gb-spotlight-20000918-01 \\
\hline \hline ArticleCitationID & $:$ & spotlight-20000918-01 \\
\hline \hline ArticleSequenceNumber & $:$ & 206 \\
\hline \hline ArticleCategory & $:$ & Research news \\
\hline \hline ArticleFirstPage & $:$ & 1 \\
\hline \hline ArticleLastPage & $:$ & 2 \\
\hline \hline & $:$ & RegistrationDate : 2000-09-18 \\
ArticleHistory & $:$ & OnlineDate $\quad$ 2000-09-18 \\
\hline \hline ArticleCopyright & $:$ & BioMed Central Ltd2000 \\
\hline \hline ArticleGrants & $:$ & \\
\hline \hline ArticleContext & $:$ & 130591111 \\
\hline \hline
\end{tabular}




\section{William Wells}

Email: wells@biotext.com

Cuckoos lay eggs that mimic the eggs of other bird species; those eggs are then looked after by the unsuspecting foster parent. Cuckoos have been divided into races based on the identity of the egg type that the females mimic. In the 14 September Nature Gibbs et al. report that only female cuckoos observe 'race' boundaries (Nature 2000, 407:183-186). Mitochondrial DNA, which is passed solely through the female line, occurs in race-specific haplotypes. But nuclear DNA, which segregates through both sexes, appears to be well blended, suggesting that the males do not observe race boundaries. Thus, genes controlling egg coloring are probably located on the female-specific $\mathrm{W}$ chromosome.

\section{References}

1. Host-race formation in the common cuckoo.

2. Nature, [http://www.nature.com/nature/] 